
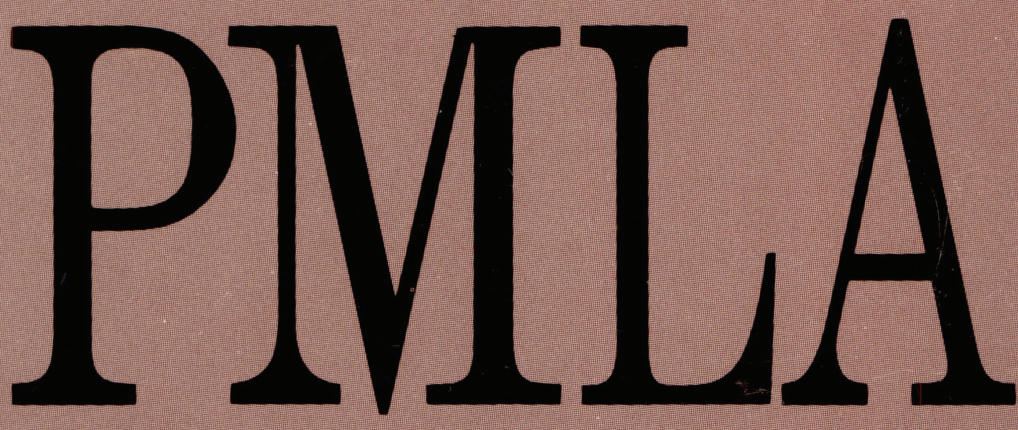

\title{
Publications of the
}

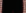

\section{Modern Language}

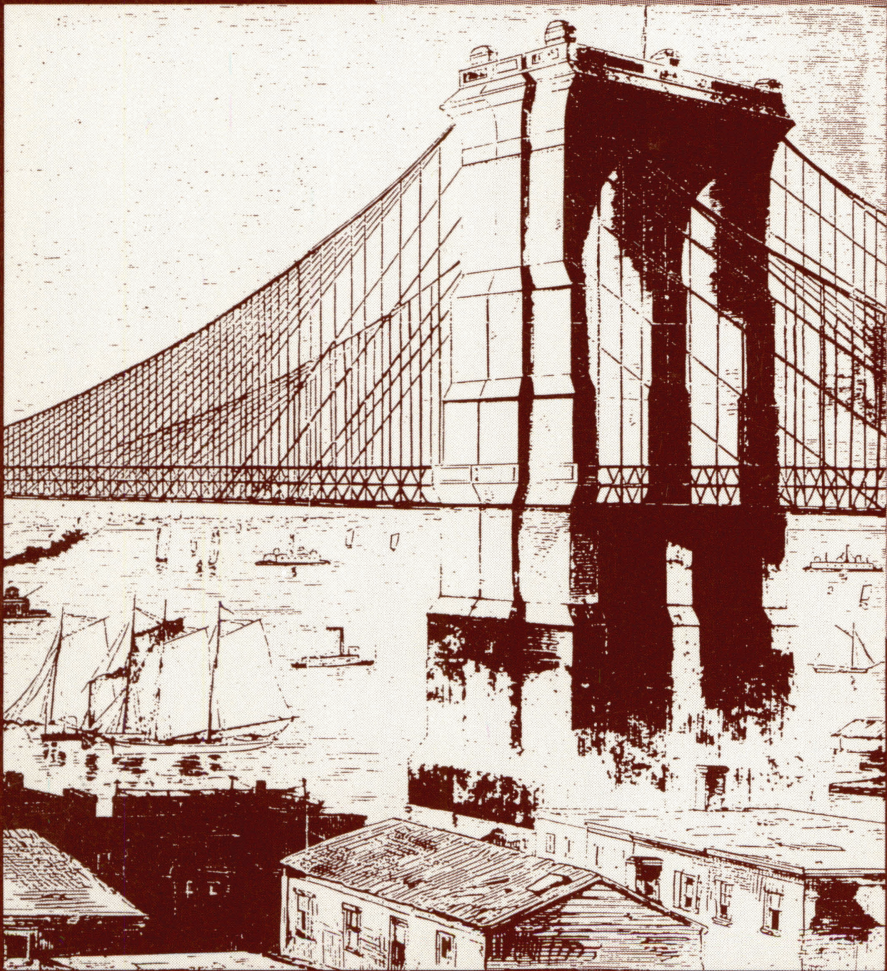

Program for the 108th Convention

NOVEMBER

\section{Association}

of America
1992 


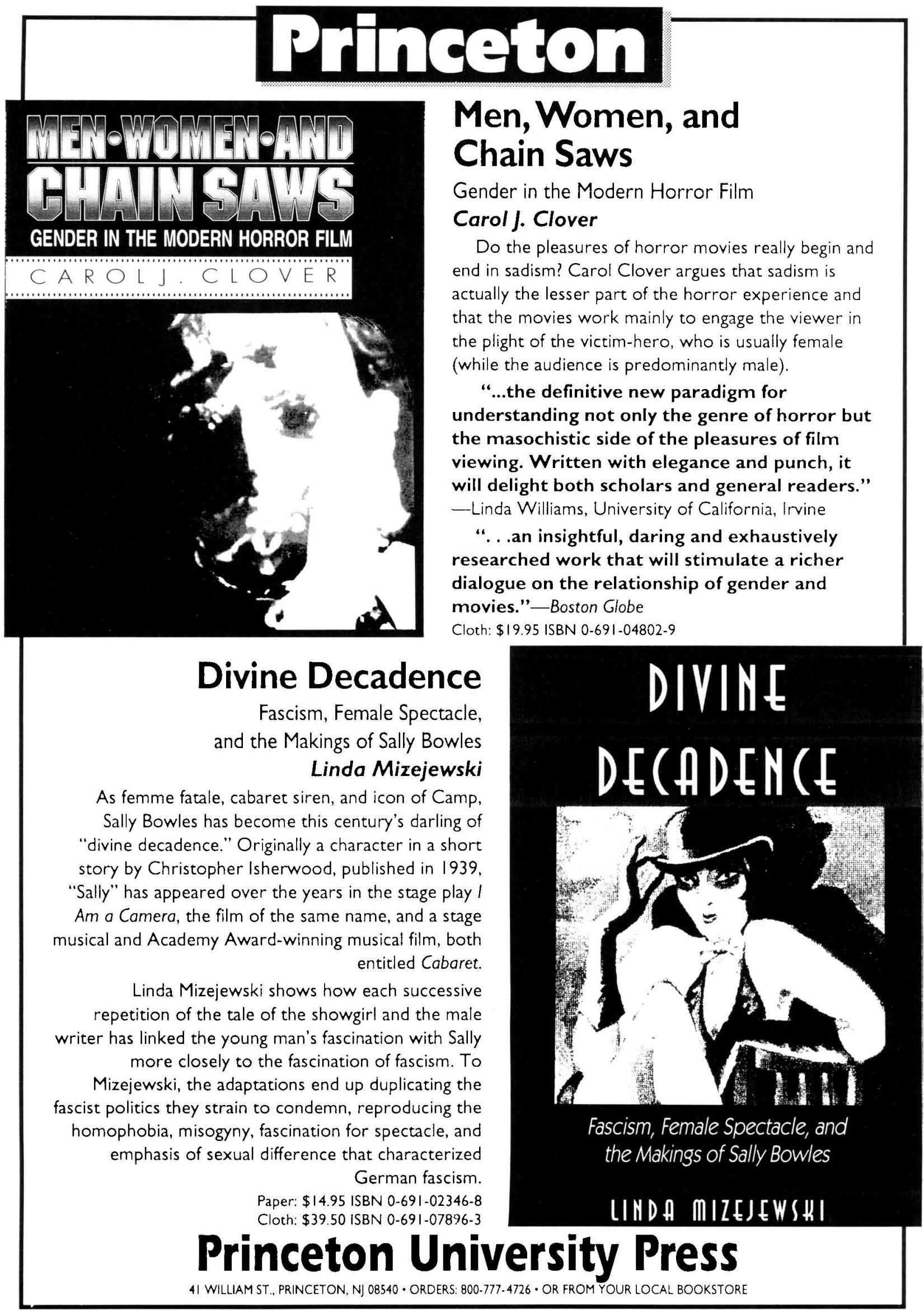




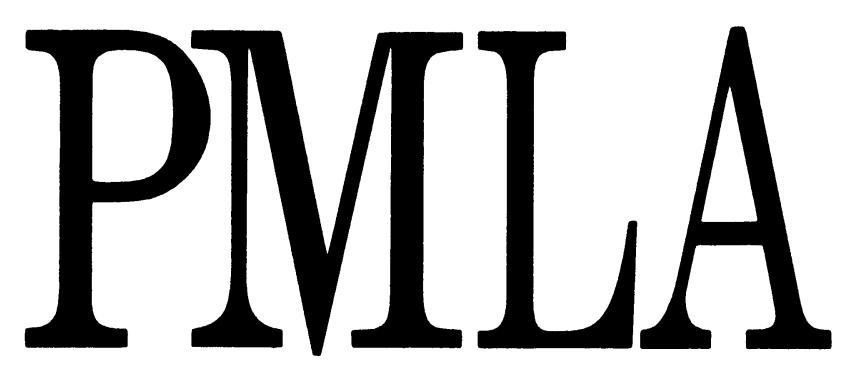

Publications of the

Modern Language Association of America

\section{Program of the 1992 Convention \\ New York, New York \\ 27-30 December}

This program is dedicated to the Library of Congress Center for the Book, whose 1992 theme is Explore New WorldsREAD!

Volume 107, Number 6

Published six times a year by the association 


\section{The Modern Language Association of America}

Officers for the Year 1992

\author{
Executive Council \\ For the term ending 31 December 1992
}

For the term ending 31 December 1993

For the term ending 31 December 1994

For the term ending 31 December 1995

Trustees of Invested Funds
President: HOUSTON A. BAKER, JR., University of Pennsylvania First Vice President: ELAINE MARKS, University of Wisconsin, Madison Second Vice President: PATRICIA MEYER SPACKS, University of Virginia Executive Director: PHYLLIS FRANKLIN

ANDREW P. DEBICKI, University of Kansas ELAINE SHOWALTER, Princeton University DOMNA C. STANTON, University of Michigan, Ann Arbor

SARA CASTRO-KLAREN, Johns Hopkins University GERALD GRAFF, University of Chicago CLAIRE KRAMSCH, University of California, Berkeley NELLIE Y. MCKAY, University of Wisconsin, Madison STEPHEN GREENBLATT, University of California, Berkeley MICHAEL HOLQUIST, Yale University JACK ZIPES, University of Minnesota, Minneapolis

MARTHA BANTA, University of California, Los Angeles MARIANNE HIRSCH, Dartmouth College NAOMI SCHOR, Duke University NANCY A. WALKER, Vanderbilt University

CAROLYN G. HEILBRUN, New York, New York HUGH O'NEILL, New York, New York MALCOLM B. SMITH (Managing Trustee), New York, New York

PMLA (ISSN 0030-8129) is published six times a year, in January, March, May, September, October, and November, by the Modern Language Association of America. Membership in the association is open to persons who are professionally interested in the modern languages and literatures. Annual dues, which include subscription to $P M L A$, are based on members' incomes and are graduated as follows: student members (four years maximum), $\$ 20$; new regular members (first year), $\$ 35$; regular members (income under $\$ 15,000$ ), $\$ 25$; regular members (income $\$ 15,000$ $\$ 20,000$ ), $\$ 40$; regular members (income $\$ 20,000-\$ 30,000$ ), $\$ 50$; regular members (income $\$ 30,000-\$ 40,000$ ), $\$ 65$; regular members (income $\$ 40,000-\$ 50,000$ ), $\$ 75$; regular members (income $\$ 50,000-\$ 60,000$ ), $\$ 85$; regular members (income $\$ 60,000-\$ 70,000$ ), $\$ 95$; regular members (income $\$ 70,000-\$ 80,000)$, $\$ 105$; regular members (income over $\$ 80,000$ ), $\$ 125$; foreign members, same as regular members (use the Americandollar equivalent to ascertain the dues category). Membership applications are available on request.

The subscription price of PMLA for libraries and other institutions is $\$ 100$. A subscription including a bound volume at the end of the year is $\$ 235$, domestic and foreign. Agents deduct $4 \%$ as their fee. Single copies of the January, March, May, and October issues may be obtained for $\$ 12$ each; the November (Program) issue for $\$ 35$; the September (Directory) issue for $\$ 50$. These prices will go into effect for all volumes on 1 January 1993.

Issues for the current year are available from the Member and Customer Services Office of the association (212 614-6377). Claims for undelivered issues will be honored if they are received within one year of the publication date; thereafter the single-issue price will be charged.

For information about the availability of back issues, inquire of Kraus Reprint, Millwood, NY 10546; 914 762-2200. Early and current volumes may be obtained on microfilm from University Microfilms, Ann Arbor, MI 48106. Purchase of current volumes on film is restricted to subscribers of the journal.

The office of publication and editorial offices are located at 10 Astor Place, New York, NY 10003-6981; 212 475-9500.

All communications including notices of changes of address should be sent to the Member and Customer Services Office of the association.

If a change of address also involves a change of institutional affiliation, that office should be informed of this fact at the same time.

Second-class postage paid at New York, NY, and at additional mailing office.

(c) 1992 by The Modern Language Association of America.

Library of Congress Catalog Card Number 12-32040. United States Postal Service Number 449-660.

POSTMASTER: Send address changes to PMLA, Member and Customer Services Office, Modern Language Association of America, 10 Astor Place, New York, NY 10003-6981. 


\section{Contents}

Cover illustration: View of the Brooklyn Bridge from the Brooklyn side. Manhattan is in the background. Courtesy of the Museum of the City of New York.
About the MLA Convention . . . . . . . . . . . . 1356

Individual Convention Program . . . . . . . . . . . 1364

Location of Meeting Rooms . . . . . . . . . . . . . 1365

Floor Plan of New York Hilton and Towers . . . . . . 1367

Floor Plan of Sheraton New York Hotel and Towers . . . 1368

Floor Plan of Sheraton Manhattan . . . . . . . . . . 1369

Floor Plan of Omni Park Central . . . . . . . . . . . 1370

Exhibitors . . . . . . . . . . . . . . . . 1371

Floor Plan of the Exhibit Area . . . . . . . . . . . 1373

Map of New York . . . . . . . . . . . . . . . . 1374

Indexes

Meetings Open to the Public . . . . . . . . . . . 1375 Forums 1375

Special Events 1375

Division Meetings . . . . . . . . . . . . . 1376

Discussion Group Meetings . . . . . . . . . . . . . 1378

American Literature Section Meetings . . . . . . . . 1378

Allied Organization Meetings . . . . . . . . . . . . 1379

MLA Meetings . . . . . . . . . . . . . . . 1382

Subject Index to All Meetings . . . . . . . . . . . . 1383

Program Participants . . . . . . . . . . . . . . 1396

\section{Program}

Sunday, 27 December . . . . . . . . . . . . . . . 1408

Monday, 28 December . . . . . . . . . . . . . . . 1418

Tuesday, 29 December . . . . . . . . . . . . . . . 1454

Wednesday, 30 December . . . . . . . . . . . . . 1491

Executive Committees . . . . . . . . . . . . . . . 1518 Division Executive Committees 1518 Discussion Group Executive Committees 1525 American Literature Section Committees 1527

Allied Organizations Sponsoring Sessions . . . . . . . . 1529

Index of Advertisers . . . . . . . . . . . . . . . . 1533 